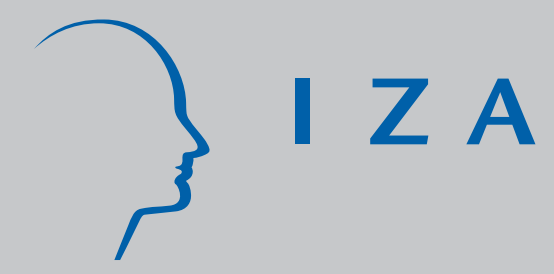

IZA DP No. 2088

Migration's Income and Poverty Impact Has Been Underestimated

Maurice Schiff

April 2006 


\title{
Migration's Income and Poverty Impact Has Been Underestimated
}

\author{
Maurice Schiff \\ World Bank and IZA Bonn
}

\section{Discussion Paper No. 2088 \\ April 2006}

\author{
IZA \\ P.O. Box 7240 \\ 53072 Bonn \\ Germany \\ Phone: +49-228-3894-0 \\ Fax: +49-228-3894-180 \\ Email: iza@iza.org
}

\begin{abstract}
Any opinions expressed here are those of the author(s) and not those of the institute. Research disseminated by IZA may include views on policy, but the institute itself takes no institutional policy positions.

The Institute for the Study of Labor (IZA) in Bonn is a local and virtual international research center and a place of communication between science, politics and business. IZA is an independent nonprofit company supported by Deutsche Post World Net. The center is associated with the University of Bonn and offers a stimulating research environment through its research networks, research support, and visitors and doctoral programs. IZA engages in (i) original and internationally competitive research in all fields of labor economics, (ii) development of policy concepts, and (iii) dissemination of research results and concepts to the interested public.
\end{abstract}

IZA Discussion Papers often represent preliminary work and are circulated to encourage discussion. Citation of such a paper should account for its provisional character. A revised version may be available directly from the author. 
IZA Discussion Paper No. 2088

April 2006

\section{ABSTRACT}

\section{Migration's Income and Poverty Impact Has Been Underestimated}

This paper examines two issues associated with the impact of migration on household income and poverty. First, existing studies have typically overlooked a feature of migration that should be taken into account in estimating its impact, namely the fact that migration changes the size of the household. The 'corrected' impact that does take the change in household size into account is presented analytically and is estimated on the basis of data from Ghana's GLSS household survey. The corrected impact is shown to be three to five times larger for income and two to three times larger for poverty than is obtained from standard analysis. Second, existing studies examine migration's impact on the poverty of the entire sample. However, some policy questions require measures of the impact on the poverty of the migrant households themselves. The latter is shown to be twenty times larger for international migration and two to three times larger for internal migration, compared to the impact for the entire sample. It is further shown that these results hold whether the poverty measures are corrected for the change in household size.

JEL Classification: F22, I32, J61, O15, O19, R23

Keywords: migration, income, poverty, underestimation, reference groups

Corresponding author:

Maurice Schiff

Development Research Group

The World Bank

MSN MC3-303

1818 H Street NW

Washington, DC 20433

USA

Email: mschiff@worldbank.org

\footnotetext{
*I would like to thank Ileana Cristina Neagu for excellent support with data and simulations.
} 


\section{Migration’s Income and Poverty Impact Has Been Underestimated}

\section{Introduction}

Migration affects the income and expenditures of migrant households and consequently affects poverty. ${ }^{1}$ This paper focuses on two issues associated with the impact of migration on household income and poverty. The first one relates to the fact that empirical studies of the impact of migration on household income and poverty have overlooked an important component of this impact, namely the change in household size. $^{2}$ I show that the impact of migration on income (poverty) is three to five (two to three) times larger when the change in household size is taken into account.

The second issue deals with the choice of reference group. Though existing studies examine the impact on the poverty of all households in the sample, including nonmigrating ones, some policy questions require measures of the poverty impact on the migrant households themselves. The latter is shown to be some twenty times larger than the usual measure for international migration and two to three times larger for internal migration.

The paper is structured as follows. Section 2 examines the first issue and Section 3 deals with the second one. Section 4 concludes.

\section{The Overlooked Component of Migration's Impact on Income and Poverty}

The definition of the per capita household income effect of migration that is used in empirical analyses is equal to the difference between remittances obtained and the

\footnotetext{
${ }^{1}$ Income and expenditures are used interchangeably in this paper.

${ }^{2}$ These include Taylor (1992), Adams (2005), Acosta (2006), and Adams and Page (2006). Taylor et al. (2003) do not examine poverty but rather focus on income, with positive adjusted effects from internal migration in China.
} 
income the household member(s) earned before migrating, divided by the household size. This definition is wrong because an important -- and possibly the most important -element of the per capita household income effect is missing from the definition. This results in a large underestimate of the effect on per capita income and poverty reduction.

\subsection{Simple Model}

To date, analyses have focused on two effects of migration on household income and have forgotten an important third effect. Denote household income in the absence of migration by $Y$ and in the presence of migration by $Y_{M}$. Further, denote the number of migrants by $m$ and the pre-migration household size by $n$. The difference between $Y_{M}$ and $Y$ per capita in a post-migration household with $n-m$ household members is:

$$
\Delta Y_{h h} \equiv \frac{1}{n-m}\left(Y_{M}-Y\right)=\frac{1}{n-m}\left(R-y_{m}\right),
$$

where $R=$ remittances and $y_{m}=$ income the migrant earned in the source country or region before migration.

A few studies have estimated the impact of migration on per capita household income based on household surveys. These studies have done so on the basis of the definition provided in equation (1). ${ }^{3}$ In other words, they have included the two effects $R$ and $y_{m}$. The studies have typically found a positive impact of migration on household per capita income, i.e., $\Delta Y_{h h}>0$.

A third and possibly more important effect has so far been ignored. The missing benefit of migration for the remittance-receiving household is due to the fact that

\footnotetext{
${ }^{3}$ The estimation of $\Delta Y_{h h}$ requires correction for both selectivity and endogeneity biases.
} 
expenditures on food, clothing and other consumption items incurred by a migrant take place in the destination country or region rather than at home. A migrant's income is first used for living expenses and only then is (part of) the remainder remitted to the migrant's household. Thus, household members who remain in the source country benefit because the new household income is shared by fewer people. Similarly, migrants use housing space in the destination country or region rather than at home. This implies a benefit for those household members remaining in the source country because of the increase in the per capita housing space or because of the possibility of renting one or more rooms out.

Thus, it is incorrect to divide both $Y_{M}$ and $Y$ by the same number of household members $n-m$ in order to obtain the effect of migration on per capita household income. As a first approximation, the correct impact $\Delta Y_{h h}^{*}$ of migration on per capita household income is:

$$
\Delta Y_{h h}^{*}=\frac{Y_{M}}{n-m}-\frac{Y}{n} .
$$

Equation (2) is a first approximation because it assumes that migrants' expenditures are identical to those of the rest of the household before migration. The difference between the corrected measure of the impact of migration on per capita household income $\Delta Y_{h h}^{*}$ and the existing one $\Delta Y_{h h}$ is

$$
\Delta Y_{h h}^{*}-\Delta Y_{h h}=\left(\frac{m}{n-m}\right) \frac{Y}{n},
$$


i.e., the underestimate of the correct impact of migration on per capita household income is a fraction $m /(n-m)$ of the pre-migration per capita household income. ${ }^{4}$

\subsection{Simulation}

The simulation is based on expenditure data from an LSMS-type household survey for Ghana (GLSS). Migrant households have members that migrated internally, internationally or both. Some sample statistics are provided in Table 1.

The GLSS survey does not provide information about the identity of the sender or senders of the remittances. I assume for simplicity that remittances obtained are sent by a household member, i.e., by someone who lived under the same roof as the household members remaining in the source country or region. That person may be a direct member of the family (spouse, child, parent, sibling), a more distant family member (e.g., cousin, nephew) or not a family member (e.g., a close friend).

Table 1 presents information on the absolute and relative size of the group of nonmigrant, internal-migrant and international-migrant households. It shows that 59\% (36\%) (8\%) of sample households receive no (internal) (international) remittances, with the sum of the shares equal to $103 \%$ because about $3 \%$ of households receive both internal and international remittances. Among remittance-receiving households, $81.8 \%$ receive internal remittances and $18.2 \%$ receive international ones. $y_{m}$

\footnotetext{
${ }^{4}$ For instance, assume a household with $n=5$ members, with one migrant $(m=1)$, and with $R=y_{m}$. Then, $Y_{M}=Y$ and the impact $\Delta Y_{h h}=0$ according to the standard definition (equation 1). However, according to the correct definition, the impact $\Delta Y_{h h}^{*}=1 / 4=25 \%$.
} 
Based on expenditure and remittance data for households in each group, I estimate the impact of migration on per capita household expenditures and poverty with the standard methodology as well as by taking the change in household size into account.

The first set of effects is shown in Table 2a, and the second set of effects in Table 2b. Table $2 \mathrm{~b}$ shows bold figures in the last three columns. These represent the ratio of the results that take the change in household size into account (from Table $2 \mathrm{~b}$ ) to the result without adjusting for the change in household size (from Table 2a). The bold figures indicate that the impact of migration and remittances on household per capita income is between 3.3 and 5 times larger when the change in household size is taken into account. For instance, for all migrant households (Column 5), the standard estimated increase in income is $7.4 \%$ while adjusting for the change in household size results in a $33.2 \%$ increase, an effect almost 4.5 times larger.

Similarly, the impact on the three poverty indices ${ }^{5}$ is between 2 and 3 times larger when the change in household size is taken into account. For instance, the reduction in the severity of poverty for all migrants is $8.5 \%$ in Table $2 \mathrm{a}$ and $18 \%$ in Table $2 \mathrm{~b}$, or an effect that is 2.1 times larger.

This case illustrates the importance of taking the change in household size into account when estimating the impact of migration and remittances. Incorporating that effect raises the impact of migration on per capita household income in the case of

\footnotetext{
5 Three measures of poverty are presented in Table 2: the poverty headcount, the average poverty gap and the average squared poverty gap. The poverty headcount is the share of all households that are below the poverty line. The average poverty gap measures the gap that exists on average between the poverty line and hh income, which tells us how much lower the poor households' income is from the poverty line. The average squared poverty gap is a measure where a household's weight increases with its poverty gap.
} 
Ghana's GLSS survey by between $230 \%$ and $400 \%$ and the impact of migration on poverty by between $100 \%$ and $200 \%$.

\section{Reference Group}

A government aiming to reduce poverty would typically examine a variety of policy instruments and might consider the promotion of migration as one of them. Its decisions would likely depend on which instruments or which package of instruments including the promotion of internal and international migration -- would best achieve its objectives. The information provided in Table 2 would not help in this case because it refers to the impact of migration on the poverty of all households, including those without migrants.

In order to answer the question about the impact of migration on the income and poverty of migrant households, one needs to compare their own situation in the pre- and post-migration state. The reference group in this case is the group of migrant households rather than all the households in the sample.

Table 3 provides information on the income and poverty impact of migration for the various groups listed in Table 1, both with the standard methodology (Table 3a) and by taking the change in household size into account (Table 3b). As one would expect, all the ratios of effects of Tables $3 b$ to $3 a$ are very close to the corresponding ratios of effects of Tables $2 \mathrm{~b}$ to 2a.

It should come as no surprise that the effects in Table 3 are much larger than those

in Table 2, given that Table 2 examines the impact of migration on the poverty of the full sample while Table 3 looks at the poverty impact within each group of migrant 
households. The effects in Table 3b for internal (and for total) migration are two to three times larger than those in Table $2 \mathrm{~b}$ for all three poverty measures as well as for income. For instance, Table 3b shows that internal migration reduces the poverty headcount of the households with internal migrants by $30.14 \%$, while Table $2 \mathrm{~b}$ shows that it reduces the poverty headcount for all households by $10.77 \%$, with the former effect 2.8 times larger than the latter one.

On the other hand, the poverty effects for the households with international migrants (Table 3b) is about twenty times larger than the corresponding effects for all households (Table 2b), and the effect on household income is about nine times larger. The reason is that the share of households with international migrants is small but that the remittances they send are relatively large.

Thus, a government considering the promotion of migration as a means of reducing poverty would be likely to promote international rather than internal migration. The decision would also depend on the cost of promoting such migration, with international migration likely to be more costly in general than internal migration in the case of South-North migration, though not necessarily for South-South migration. ${ }^{6}$

\section{Conclusion}

The analysis presented in this paper leads to several conclusions. First, it is clear that abstracting from changes in the size of migrant households results in important negatively-biased estimates of the impact of migration on income and poverty. Based on data from Ghana's GLSS household survey, the impact on income is three to five times

\footnotetext{
${ }^{6}$ It is likely to be cheaper to migrate to Santiago of Chile from an Argentine city on Chile's border like Mendoza than from Mendoza to Buenos Aires.
} 
larger, and the impact on poverty two to three times larger, than obtained with the standard methodology.

Second, different policy-related questions require different reference groups. As far as the choice of poverty-reducing instruments is concerned, the poverty impact should be estimated for the group of migrant households rather than for the entire sample. The impact of migration on poverty for the group of migrant households is much larger than the impact obtained for the entire sample. It is some twenty times larger for internationalmigrant households and two to three times larger for internal-migrant households. Consequently, a government using migration as a poverty-reducing instrument would be likely to promote international rather than internal migration. The decision would of course also depend on the cost of promoting such migration.

\section{References}

Acosta, Pablo. 2006. “Labor Supply, School Attendance, and Remittances from International Migration: The Case of El Salvador.” Policy Research Working Paper. World Bank.

Adams, Richard H., Jr. 2005. “Remittances, Poverty, and Investment in Guatemala.' Chapter 2 in Caglar Ozden and Maurice Schiff (eds.) International Migration, Remittances and the Brain Drain. Palgrave Macmillan: New York (for the World Bank).

and John Page. 2006. “'Do International Migration and Remittances Reduce Poverty in Developing Countries?’' World Development.

Taylor J. Edward. 1992. "Remittances and Inequality Reconsidered: Direct, Indirect, and Intertemporal Effects.”’ Journal of Policy Modeling 14 (2): 18-2.

Scott Rozelle and Alan de Brauw. 2003. "Migration and Incomes in Source Communities: A New Economics of Migration Perspective from China.' Economic Development and Cultural Change 52 (1): 75-102. 
Table 1. Summary statistics*

\begin{tabular}{|l|c|c|c|c|c|}
\hline Indicators & $\begin{array}{c}\text { All } \\
\text { households }\end{array}$ & $\begin{array}{c}\text { Receive no } \\
\text { remittances }\end{array}$ & $\begin{array}{c}\text { Receive } \\
\text { internal } \\
\text { remittances }\end{array}$ & $\begin{array}{c}\text { Receive } \\
\text { Receive } \\
\text { international } \\
\text { remittances }\end{array}$ & $\begin{array}{c}\text { internal and } \\
\text { international } \\
\text { remittances }\end{array}$ \\
\hline & $(1)$ & $(2)$ & $(3)$ & $(4)$ & $(5)$ \\
\hline Sample size & 5998 & 3517 & 2139 & 488 & 2481 \\
\hline $\begin{array}{l}\text { Relative sample } \\
\text { size }\end{array}$ & $100 \%$ & $59 \%$ & $36 \%$ & $8 \%$ & $41 \%$ \\
\hline $\begin{array}{l}\text { Average } \\
\text { household size }\end{array}$ & 4.31 & 4.51 & 3.99 & 4.2 & 4.02 \\
\hline
\end{tabular}

* "Sample size" and "Relative sample size" figures in Column (5) are smaller than the sum of the corresponding figures in Columns (3) and (4) because some households receive both internal and international remittances and are thus included in both columns. 
TABLE 2. Impact on Income and Poverty (\%) - Whole Sample

\section{a. Abstracting from the change in household size}

\begin{tabular}{|c|c|c|c|c|c|c|c|}
\hline \multirow[b]{2}{*}{$\begin{array}{l}\text { Standard } \\
\text { results }\end{array}$} & \multirow[b]{2}{*}{$\begin{array}{l}\text { Receive no } \\
\text { remittances }\end{array}$} & \multirow[b]{2}{*}{$\begin{array}{c}\text { Receive } \\
\text { internal } \\
\text { remittances }\end{array}$} & \multirow[b]{2}{*}{$\begin{array}{c}\text { Receive } \\
\text { international } \\
\text { remittances }\end{array}$} & \multirow[b]{2}{*}{$\begin{array}{c}\text { Receive } \\
\text { internal and } \\
\text { international } \\
\text { remittances }\end{array}$} & \multicolumn{3}{|c|}{ Percentage change } \\
\hline & & & & & $\begin{array}{l}\text { Internal } \\
\text { vs. no } \\
\text { remittances }\end{array}$ & $\begin{array}{l}\text { International } \\
\text { vs. no } \\
\text { remittances }\end{array}$ & $\begin{array}{l}\text { Internal and } \\
\text { international } \\
\text { vs. no } \\
\text { remittances }\end{array}$ \\
\hline & (1) & (2) & (3) & (4) & (5) & (6) & $(7)$ \\
\hline $\begin{array}{l}\text { Poverty } \\
\text { headcount }\end{array}$ & 41.02 & 39.50 & 40.68 & 39.16 & $-3.72 \%$ & $-0.85 \%$ & $-4.55 \%$ \\
\hline $\begin{array}{l}\text { Average } \\
\text { poverty gap }\end{array}$ & 14.61 & 13.85 & 14.47 & 13.66 & $-5.25 \%$ & $-0.98 \%$ & $-6.54 \%$ \\
\hline $\begin{array}{l}\text { Average } \\
\text { squared } \\
\text { poverty gap }\end{array}$ & 6.89 & 6.42 & 6.80 & 6.30 & $-6.70 \%$ & $-1.24 \%$ & $-8.53 \%$ \\
\hline $\begin{array}{l}\text { Mean per } \\
\text { capita } \\
\text { household } \\
\text { expenditure }\end{array}$ & $1,435,879$ & $1,514,743$ & $1,476,031$ & $1,542,228$ & $5.49 \%$ & $2.80 \%$ & $7.41 \%$ \\
\hline $\mathrm{N}$ & 5998 & 5998 & 5998 & 5998 & & & \\
\hline
\end{tabular}

\section{b. Accounting for the change in household size}

\begin{tabular}{|c|c|c|c|c|c|c|c|}
\hline \multirow[b]{2}{*}{ New results } & \multirow[b]{2}{*}{$\begin{array}{c}\text { Receive } \\
\text { no } \\
\text { remittance } \\
\mathrm{s} \\
\end{array}$} & \multirow[b]{2}{*}{$\begin{array}{l}\text { Receive } \\
\text { internal } \\
\text { remittances }\end{array}$} & \multirow{2}{*}{$\begin{array}{c}\text { Receive } \\
\text { international } \\
\text { remittances } \\
\text { (from African } \\
\text { or other } \\
\text { countries) } \\
\end{array}$} & \multirow[b]{2}{*}{$\begin{array}{c}\text { Receive } \\
\text { internal and } \\
\text { international } \\
\text { remittances }\end{array}$} & \multicolumn{3}{|c|}{ Percentage change } \\
\hline & & & & & $\begin{array}{l}\text { Internal } \\
\text { vs. no } \\
\text { remittances }\end{array}$ & $\begin{array}{l}\text { Internationa } \\
\text { I vs. no } \\
\text { remittances }\end{array}$ & $\begin{array}{l}\text { Internal and } \\
\text { international } \\
\text { vs. no } \\
\text { remittances }\end{array}$ \\
\hline & (1) & (2) & (3) & (4) & (5) & (6) & $(7)$ \\
\hline \multirow[b]{2}{*}{ Poverty headcount } & \multirow[b]{2}{*}{41.02} & \multirow[b]{2}{*}{36.60} & \multirow[b]{2}{*}{40.29} & \multirow[b]{2}{*}{36.27} & $-10.77 \%$ & $-1.79 \%$ & $-11.59 \%$ \\
\hline & & & & & 2.90 & 2.11 & 2.55 \\
\hline \multirow{2}{*}{$\begin{array}{l}\text { Average poverty } \\
\text { gap }\end{array}$} & \multirow[b]{2}{*}{14.61} & \multirow[b]{2}{*}{12.63} & \multirow[b]{2}{*}{14.32} & \multirow[b]{2}{*}{12.45} & $-13.57 \%$ & $-1.98 \%$ & $-14.77 \%$ \\
\hline & & & & & 2.58 & 2.03 & 2.26 \\
\hline \multirow{2}{*}{$\begin{array}{c}\text { Squared poverty } \\
\text { gap }\end{array}$} & \multirow[b]{2}{*}{6.89} & \multirow[b]{2}{*}{5.77} & \multirow[b]{2}{*}{6.72} & \multirow[b]{2}{*}{5.64} & $-16.19 \%$ & $-2.47 \%$ & $-18.05 \%$ \\
\hline & & & & & 2.42 & 1.98 & 2.12 \\
\hline \multirow{2}{*}{$\begin{array}{l}\text { Mean per capita } \\
\text { household } \\
\text { expenditure }\end{array}$} & \multirow[b]{2}{*}{$1,435,879$} & \multirow[b]{2}{*}{$1,829,547$} & \multirow[b]{2}{*}{$1,569,810$} & \multirow[b]{2}{*}{$1,912,279$} & $27.42 \%$ & $9.33 \%$ & $33.18 \%$ \\
\hline & & & & & 4.99 & 3.34 & 4.48 \\
\hline $\mathrm{N}$ & 5998 & 5998 & 5998 & 5998 & & & \\
\hline
\end{tabular}


TABLE 3. Impact on Income and Poverty (\%) for Remittance-Receiving Households -- Impact within Each Category

a. Abstracting from the change in household size

\begin{tabular}{|c|c|c|c|c|c|c|c|c|c|}
\hline \multirow[b]{2}{*}{$\begin{array}{l}\text { Standard } \\
\text { Results }\end{array}$} & \multirow[b]{2}{*}{$\begin{array}{l}\text { Receive no } \\
\text { internal } \\
\text { remittances }\end{array}$} & \multirow[b]{2}{*}{$\begin{array}{l}\text { Receive } \\
\text { internal } \\
\text { remittances }\end{array}$} & \multirow[b]{2}{*}{$\begin{array}{l}\text { Receive no } \\
\text { international } \\
\text { remittances }\end{array}$} & \multirow[b]{2}{*}{$\begin{array}{c}\text { Receive } \\
\text { international } \\
\text { remittances }\end{array}$} & \multirow[b]{2}{*}{$\begin{array}{l}\text { Receive no } \\
\text { remittances }\end{array}$} & \multirow[b]{2}{*}{$\begin{array}{l}\text { Receive internal } \\
\text { and international } \\
\text { remittances }\end{array}$} & \multicolumn{3}{|c|}{ Percentage change } \\
\hline & & & & & & & $\begin{array}{l}\text { Internal vs. } \\
\text { no internal } \\
\text { remittances }\end{array}$ & $\begin{array}{l}\text { International } \\
\text { vs. no } \\
\text { international } \\
\text { remittances }\end{array}$ & $\begin{array}{l}\text { Internal and } \\
\text { international } \\
\text { vs. no } \\
\text { remittances }\end{array}$ \\
\hline & (1) & (2) & (3) & (4) & (5) & (6) & (7) & (8) & (9) \\
\hline $\begin{array}{l}\text { Poverty } \\
\text { headcount }\end{array}$ & 43.26 & 38.66 & 25.68 & 21.55 & 40.54 & 36.24 & $-10.64 \%$ & $-16.07 \%$ & $-10.59 \%$ \\
\hline Povery gap & 14.90 & 12.58 & 8.61 & 6.72 & 13.93 & 11.75 & $-15.60 \%$ & $-21.95 \%$ & $-15.65 \%$ \\
\hline $\begin{array}{l}\text { Squared } \\
\text { poverty gap }\end{array}$ & 6.76 & 5.39 & 3.92 & 2.82 & 6.29 & 5.00 & $-20.29 \%$ & $-28.08 \%$ & $-20.54 \%$ \\
\hline $\begin{array}{l}\text { Mean per } \\
\text { capita } \\
\text { household } \\
\text { expenditure }\end{array}$ & $1,285,442$ & $1,490,423$ & $1,739,084$ & $2,189,202$ & $1,452,904$ & $1,699,494$ & $15.95 \%$ & $25.88 \%$ & $16.97 \%$ \\
\hline $\mathrm{N}$ & 2139 & 2139 & 488 & 488 & 2481 & 2481 & & & \\
\hline
\end{tabular}


b. Accounting for the change in household size

\begin{tabular}{|c|c|c|c|c|c|c|c|c|c|}
\hline \multirow[b]{2}{*}{ New results } & \multirow[b]{2}{*}{$\begin{array}{l}\text { Receive no } \\
\text { internal } \\
\text { remittances }\end{array}$} & \multirow[b]{2}{*}{$\begin{array}{c}\text { Receive } \\
\text { internal } \\
\text { remittances }\end{array}$} & \multirow[b]{2}{*}{$\begin{array}{c}\text { Receive no } \\
\text { international } \\
\text { remittances }\end{array}$} & \multirow[b]{2}{*}{$\begin{array}{c}\text { Receive } \\
\text { international } \\
\text { remittances }\end{array}$} & \multirow[b]{2}{*}{$\begin{array}{l}\text { Receive no } \\
\text { remittances }\end{array}$} & \multirow[b]{2}{*}{$\begin{array}{c}\text { Receive } \\
\text { internal and } \\
\text { international } \\
\text { remittances }\end{array}$} & \multicolumn{3}{|c|}{ Percentage change } \\
\hline & & & & & & & $\begin{array}{l}\text { Internal vs. no } \\
\text { internal } \\
\text { remittances }\end{array}$ & $\begin{array}{l}\text { International } \\
\text { vs. no } \\
\text { international } \\
\text { remittances }\end{array}$ & $\begin{array}{l}\text { Internal and } \\
\text { international } \\
\text { vs. no } \\
\text { remittances }\end{array}$ \\
\hline & (1) & $(2)$ & (3) & $(4)$ & $(5)$ & $(6)$ & $(7)$ & $(8)$ & $(9)$ \\
\hline \multirow{2}{*}{$\begin{array}{c}\text { Poverty headcount } \\
\text { (percent) }\end{array}$} & \multirow[b]{2}{*}{43.26} & \multirow[b]{2}{*}{30.23} & \multirow[b]{2}{*}{25.68} & \multirow[b]{2}{*}{16.73} & \multirow[b]{2}{*}{40.54} & \multirow[b]{2}{*}{28.32} & $-30.14 \%$ & $-34.84 \%$ & $-30.15 \%$ \\
\hline & & & & & & & 2.83 & 2.17 & 2.85 \\
\hline \multirow[b]{2}{*}{ Povery gap (percent) } & \multirow[b]{2}{*}{14.90} & \multirow[b]{2}{*}{8.82} & \multirow[b]{2}{*}{8.61} & \multirow[b]{2}{*}{4.74} & \multirow[b]{2}{*}{13.93} & \multirow[b]{2}{*}{8.22} & $-40.78 \%$ & $-44.94 \%$ & $-41.00 \%$ \\
\hline & & & & & & & 2.61 & 2.05 & 2.62 \\
\hline \multirow{2}{*}{$\begin{array}{c}\text { Squared poverty gap } \\
\text { (percent) }\end{array}$} & \multirow[b]{2}{*}{6.76} & \multirow[b]{2}{*}{3.38} & \multirow[b]{2}{*}{3.92} & \multirow[b]{2}{*}{1.79} & \multirow[b]{2}{*}{6.29} & \multirow[b]{2}{*}{3.13} & $-50.00 \%$ & $-54.17 \%$ & $-50.34 \%$ \\
\hline & & & & & & & 2.46 & 1.93 & 2.45 \\
\hline \multirow{2}{*}{$\begin{array}{l}\text { Mean per capita } \\
\text { household } \\
\text { expenditure }\end{array}$} & \multirow[b]{2}{*}{$1,285,442$} & \multirow[b]{2}{*}{$2,325,617$} & \multirow[b]{2}{*}{$1,739,084$} & \multirow[b]{2}{*}{$3,270,706$} & \multirow[b]{2}{*}{$1,452,904$} & \multirow[b]{2}{*}{$2,621,058$} & $80.92 \%$ & $88.07 \%$ & $80.40 \%$ \\
\hline & & & & & & & 5.07 & 3.40 & 4.74 \\
\hline $\mathrm{N}$ & 2139 & 2139 & 488 & 488 & 2481 & 2481 & & & \\
\hline
\end{tabular}

